RANGGA DOLI P MANURUNG DAN AYI BUDI SANTOSA

AKAR YANG MENJALAR: PERAN EMIL SALIM DALAM KEMENTERIAN PENGAWASAN

PEMBANGUNAN DAN LINGKUNGAN HIDUP DI INDONESIA 1972-1983

\title{
AKAR YANG MENJALAR: PERAN EMIL SALIM DALAM KEMENTERIAN PENGAWASAN PEMBANGUNAN DAN LINGKUNGAN HIDUP DI INDONESIA 1972-1983
}

\author{
Oleh: \\ Rangga Doli P Manurung dan Ayi Budi Santosa ${ }^{1}$
}

\begin{abstract}
This article based on writer interest on New Order history, especially regarding the Ministry of State for Development and Environment Supervision. After research found that Emil Salim was the man behind the establishment of The Environment Ministry and acknowledged as the first minister in 1978 - 1993. However, the study focused on Emil Salim first period as Minister in 1978 - 1983. Thus, it will be interesting if Emil Salim role in the formation of the Ministry of State for Development and Environment Supervision and his policy as Minister from this sector has furthermore studied. This research intended to explain the formation process of the Ministry and analyzed Emil Salim policy on protecting the environment and managing development. This research used historical research methods that is heuristic, critic, and historiography. Based on the research, Emil Salim is an economist who trusted by the New Order government to manage development and environment. As a Minister, Emil Salim pioneered some policies for protecting and managing the environment. Some of his policies were Center for Environmental Studies in 1979, Kalpataru Award in 1981 and Product of Law in Constitution Number 4 the year 1982.
\end{abstract}

Keywords: Center for Environmental Studies, Development and Environment, Kalpataru Award, Product of Law in Constution Number 4 year 1982.

\section{PENDAHULUAN}

Konferensi internasional lingkungan hidup atau United Nations Conference on Human Environment (UNCHE), tahun 1972 di Stockholm, Swedia adalah konferensi yang sangat bersejarah, karena merupakan konferensi pertama tentang lingkungan hidup yang diprakarsai oleh PBB dan diikuti oleh wakil dari 114 negara.
Konferensi ini juga merupakan penentu langkah awal upaya penyelamatan lingkungan hidup secara global. Dalam konferensi Stockholm inilah untuk pertama kali motto "Hanya ada satu bumi" (Only One Earth) untuk semua manusia di perkenalkan dan motto tersebut sekaligus menjadi motto konferensi (Salim, 1979, hlm. 77). Selain itu konferensi Stockholm menetapkan tanggal 5 Juni

\footnotetext{
${ }^{1}$ Rangga Doli P Manurung adalah mahasiswa pada Departemen Pendidikan Sejarah FPIPS UPI, Ayi Budi Santosa adalah dosen pembimbing I. Penulis dapat dihubungi di alamat email : ranggadolipm@gmail.com.
} 
yang juga hari pembukaan konferensi tersebut sebagai hari lingkungan hidup se-dunia (World Environment Day). Kesepakatan mengenai keterkaitan antara konsep pembangunan dan pengelolaan lingkungan hidup. Persoalan lingkungan hidup diidentikkan dengan kemiskinan, keterbelakangan, tingkat pembangunan yang tertinggal dan pendidikan yang tentu rendah pula, intinya faktor kemiskinan yang menjadi penyebab utama kerusakan lingkungan hidup didunia (Suparmoko, 1997, hlm. 73). Sehingga dalam forum tersebut disepakati suatu persepsi bahwa kebijakan lingkungan hidup harus terkait dengan kebijakan pembangunan nasional.

Indonesia yang merupakan salah satu peserta dari Konferensi Tingkat Tinggi PBB di Stockholm Swedia juga sebagai negara yang memiliki keanekaragaman hayati yang kaya dan program unggulannya ialah pembangunan salah satunya restorasi dalam bentuk produksi dan pengelolahan bahan pangan (Program Revolusi Hijau) sehingga dapat berswasembada pangan, mulai meyadari bahwa diperlukan suatu instansi, organisasi ataupun suatu wadah yang berkonsentrasi pada lingkungan hidup, tepatnya pada pembangunan yang ramah lingkungan atau pembangunan yang tidak merusak lingkungan, sehingga wadah tersebut dapat meminimalisir efek lingkungan hidup dari program pembangunan (Salim, 1979, hlm. 35).

Walaupun terkesan seperti alat legitimasi atau langkah politis agar negara-negara yang hadir pada konferensi PBB di Stockholm memandang Indonesia peduli akan lingkungan hidup atau dapat dikatakan sebagai sebuah upaya penggembosan keradikalan gerakan mahasiswa agar kalangan cendekiawan
Indonesia mencabut "Mosi Tidak Percaya" lewat pernyataan Dewan-Dewan Mahasiswa yang berkumpul di ITB tahun 1978 kepada pemerintahan Presiden Soeharto yang terkesan semena-mena dalam mengolah berbagai macam Sumber Daya Alam (Aditjondro 2003a, hlm. x).

Wadah tersebut terbentuk secara bertahap mulai dari Panitia Perumus dan Rencana Kerja bagi Pemerintah di Bidang Lingkungan Hidup tahun 1972, selanjutnya Panitia Inventarisasi dan Evaluasi Kekayaan Alam tahun 1975, hingga Kementerian Pengawasan Pembangunan dan Lingkungan Hidup tahun 1978. Emil Salim tentunya memiliki andil besar dalam Ketiga organisasi tersebut khususnya dalam Kemeterian Pengawasan Pembangunan dan Lingkungan Hidup tahun 1978-1983 yang di nahkodai oleh Emil Salim Wiryono (, 2013, hlm. 8).

Setelah terbentuknya Men-PPLH, tepatnya di penghujung Repelita II seperti menjadi krikil dalam sepatu bagi Kementerian Pengawasan Pembangunan dan Lingkungan Hidup (Men-PPLH) dalam menjalankan tugas serta wewenangnya. Awalnya institusi ini dibentuk sebagai wadah di bidang lingkungan hidup dan secara politis, dianggap dapat meredam "mosi tidak percaya" Dewan-Dewan Mahasiswa, malah memberikan dampak yang kurang baik bagi kementerian lainnya di pemerintahan pusat karena dianggap mempersempit ruang gerak kementerian lain dalam menjalankan tugas dan wewenang apabila bersangkut paut dengan pembangunan dan lingkungan hidup.

Hal ini menggelitik penulis untuk selanjutnya menjadikan fokus penelitian penulis dengan menjabarkan proses terbentuknya Kementrian Pengawasan 
RANGGA DOLI P MANURUNG DAN AYI BUDI SANTOSA

AKAR YANG MENJALAR: PERAN EMIL SALIM DALAM KEMENTERIAN PENGAWASAN

PEMBANGUNAN DAN LINGKUNGAN HIDUP DI INDONESIA 1972-1983

Pembangunan dan Lingkungan Hidup (Men-PPLH) sampai pengaruh keberadaan Men-PPLH terhadap Pembangunan Repelita II dan III dari sudut pandang Emil Salim sebagai tokoh yang dianggap peneliti berperan besar dalam pembentukan Kementerian ini.

Beberapa pristiwa atau kejadian ini diuraikan dengan dasar dari Keputusan Presiden No. 16 Tahun 1972 Indonesia membentuk Panitia Interdepartemental atau Panitia Perumus dan Rencana Kerja Bagi Pemerintah di Bidang Lingkungan Hidup (Arsip Sekretaris Negara tahun 1972) panitia ini diketuai oleh Emil Salim. Selanjutnya tiga tahun kemudian Presiden Soeharto mengeluarkan Keputusan Presiden No. 27 Tahun 1975 Tentang Pembentukan Panitia Inventarisasi dan Evaluasi Kekayaan Alam (Arsip Sekretaris Negara tahun 1975) yang bertugas sebagai Penyusuan Perangkat Perundangan, Kelembagaan, RUU dan Persiapan Pembentukan Kelompok Kerja Hukum dan Aparatur Dalam Pengelolaan Sumber Daya Alam (SDA) dan Lingkungan Hidup tahun 1975. Selanjutnya tentu peneliti mengkaji lebih dalam kembali mengenai kebijakan-kebijakan dari menteri pertama Men-PPLH ini selama dalam masa jabatannya dari kurung waktu 1978 hingga 1983 yang dianggap oleh penulis menjadi akar dari sebuah keadilan bagi lingkungan di Indonesia.

Penulis mengawali kajiannya dari seorang tokoh yang bernama Emil Salim, karena penulis beranggapan Emil Salim memilikiposisiyangbegitu sentralterhadap keberlangsungan lingkungan hidup di Indonesia baik dari sisi perlindungannya maupun pengelolaannya. Walaupun Emil Salim besar dengan pendidikan ekonominya yang diperoleh dari Fakultas Ekonomi Universitas Indonesia tahun 1951 sampai 1959 dengan predikat yang terbukti aktif sebagai seorang mahasiswa dengan rentetan pencapaian dan rekam jejak organisasi-organisasi yang digelutinya pada tingkatan intra universiter (Noeradi, 2000, hlm. 350-351).

Kemudian, Emil Salim berkesempatan untuk melanjutkan pendidikannya di University of California, Department of Eonomics. Tahun 1959 sampai 1964 dengan penjurusan Master of Arts (1962) dan Ph.D (1964) dengan disertasinya yang berjudul Institutional Structure and Economic Development. Setelah selesai Emil Salim mengenyam pendidikan di Amerika, Presiden Soeharto memintanya dan beberapa cendekiawan lainnya untuk menjadi pengajar ilmu ekonomi bagi para tentara. Karena pada saat itu Presiden Soeharto menyadari untuk dapat memerintah tidak cukup hanya kedisiplinan dan moral yang baik, melainkan juga mempunyai pemikiran, ide maupun konsep yang cerdas (Salim, 1979, hlm. 50). Dengan latar belakang pendidikan dan sedikit rekam jejaknya, penulis tak menyangkal bila Emil Salim dipredikatkan sebagai seorang ekonom. Hal ini semakin merangsang penulis untuk mengkaji Emil Salim.

Bagi penulis, seorang yang tidak sama sekali penulis dapati pernah bersenggama dengan lingkungan hidup, lantas menjadi seorang tokoh yang memiliki peran aktif dalam pembentukan Kementerian Pengawasan Pembangunan dan Lingkungan Hidup. Ditambah lagi Emil Salim juga memangku kebijakan sebagai menteri pertama di kementerian ini merayu penulis untuk semakin haus 
mengetahui peran serta kebijakan dan langkah politisnya untuk membangun pondasi yang kokoh untuk kementerian ini tentu untuk kelestarian lingkungan.

\section{METODE PENELITIAN}

Dalam mengkaji permasalahan yang berkaitan dengan penelitian ini, penulis menggunakan metode sejarah sebagai metode penelitiannya. metode sejarah merupakan proses menguji dan menganalisis secara kritis rekaman dan peninggalan masa lampau (Gottschalk, 2008, hlm. 39). Pada penelitian ini, metode sejarah yang akan digunakan adalah berdasarkan pada Ismaun (2005, hlm. 50) yang terdiri dari heuristik, kritik sumber, interpretasi, dan historiografi.

Setelah topik penelitian ditentukan, langkah pertama yang dilakukan penulis adalah melakukan heuristik, yaitu pencarian dan pengumpulan sumbersumber sejarah (Ismaun, 2005, hlm. 49). Pada penelitian ini penulis terfokus pada pencarian dan pengumpulan sumbersumber sejarah yang dapat dijadikan sebagai suatu bahan analisis terkait peranan Emil Salim. Dalam hal ini, penulis mencari dan mengumpulkan buku serta arsip yang penulis dapatkan sebagai sumber primer yang berkaitan dengan latar belakang Emil Salim, peran dalam pembentukan Kementerian Pengawasan Pembangunan dan Lingkungan Hidup (Men-PPLH) serta kebijakannya.

Untuk mencari kebenaran atas sumber-sumber yang telah didapatkan, maka penulis melakukan kritik terhadap sumber-sumber tersebut. Sebagaimana fungsi dari kritik sumber itu sendiri adalah untuk membedekan apa yang benar, apa yang tidak benar (palsu), apa yang mungkin dan apa yang meragukan atau mustahil (Sjamsuddin, 2012, hlm. 103). Pada tahapan ini penulis membagi dalam dua bentuk verifikasi, yaitu kritik eksternal untuk menguji integritas dan autentitas sumber secara fisik, kemudian kritik internal untuk menguji kredibilitas sumber.

Tahapan selanjutnya yang dilakukan oleh penulis adalah melakukan interpretasi. Untuk menjaga subtansi dari pemikiran-pemikirannya supaya tidak keluar dari konteks yang sebenarnya, penulis melakukan interpretasi tidak jauh dari konsepsi Emil Salim itu sendiri. Penulis menggunakan penafsiran sintesis untuk mendapatkan suatu penafsiran yang utuh. Menurut penafsiran ini tidak ada satu kategori "sebab-sebab" tunggal yang cukup untuk menjelaskan semua fase dan periode perkembangan sejarah. Artinya, perkembangan dan jalannya sejarah digerakan oleh berbagai faktor dan tenaga bersama, namun manusia tetap sebagai pemeran utamanya (Sjamsuddin, 2012, hlm. 127-132).

Historiografi menjadi fase terakhir dari metode sejarah setelah melalui tahapan uji verifikasi sumber (kritik) serta penafsiran (interpretasi). Historiografi merupakan cara penulisan, pemaparan atau pelaporan dari hasil penelitian yang telah dilakukan (Abdurahman, 2007, hlm. 76). Pada tahapan historiografi, penulis menggunakan model eksplanasi hermeneutika. Hermeneutika erat hubungannya dengan penafsiran teks-teks masa lalu dan perbuatan pelaku sejarah (Sjamsuddin, 2012, hlm. 167). 
RANGGA DOLI P MANURUNG DAN AYI BUDI SANTOSA

AKAR YANG MENJALAR: PERAN EMIL SALIM DALAM KEMENTERIAN PENGAWASAN PEMBANGUNAN DAN LINGKUNGAN HIDUP DI INDONESIA 1972-1983

\section{HASIL PENELITIAN PEMBAHASAN}

Sebagai pengejawantahan dari kesepakatan konferensi Stockholm, berdasarkan Keputusan Presiden No. 16 Tahun 1972, Indonesia membentuk panitia antar departemen yang disebut dengan Panitia Perumus dan Rencana Kerja Bagi Pemerintah di bidang Lingkungan Hidup guna merumuskan dan mengembangkan rencana kerja di bidang lingkungan hidup. Panitia yang diketuai oleh Emil Salim selaku Menteri Pendayagunaan Aparatur Negara (Men-Pan) sekaligus Wakil Ketua Badan Perencanaan Pembangunan Nasional (Bappenas) tersebut berhasil merumuskan program kebijaksanaan lingkungan hidup sebagaimana tertuang dalam Butir 10 Bab II Garis-Garis Besar Haluan Negara (GBHN) 1973-1978 dan Bab 4 Rencana Pembangunan Lima Tahun (Repelita) II dibawah pimpinan Emil Salim (Kahar dkk, 1996, hlm. 43).

Keberadaan lembaga yang khusus mengelola lingkungan hidup dirasa mendesak agar pelaksanaan pengelolaan lingkungan hidup baik di tingkat pusat maupun di daerah lebih nyata dan terjamin. Menurut Emil Salim (2000, hlm. 147) Emil Salim sendiri telah berpendapat bahwa Panitia Perumus dan Rencana Kerja Bagi Pemerintah di Bidang Lingkungan Hidup Tahun 1972 nyatanya hanyalah peredam untuk menggembosi golongan masa radikal yang memprotes kepada negara mengenai pengelolaan sumber daya alam. Selain unsur politis, Emil Salim juga beranggapan bahwa panitia ini tidak dapat membendung segala urusan dan tata kelola bagi lingkungan hidup.

Menyadari hal demikian, Emil Salim lantas mendesak pemerintah untuk memperluas dan memperdalam kajian juga gugusan tugas dalam pemetaan sumber daya alam yang selanjutnya "peta" tersebut dapat dikelola dengan baik oleh negara. Emil Salim juga menginginkan suatu badan yang dapat mengkonsep penanganan masalah terkait lingkungan hidup. Argumenn-argumen Emil Salim berserta penggiat lingkungan yang cukup relevan tersebut akhirnya di aminni oleh negara.

Sebagai hadiahnya, tiga tahun kemudian Presiden mengeluarkan Keppres No. 27 Tahun 1975. Keppres ini merupakan dasar pembentukan Panitia Inventarisasi dan Evaluasi Kekayaan Alam dengan tugas pokoknya adalah menelaah secara nasional pola-pola permintaan dan persediaan serta perkembangan teknologi, baik di masa kini maupun di masa mendatang serta implikasi sosial, ekonomi, ekologi dan politis dari polapola tersebut (Azis dkk, 2010, hlm. 197). Keppres ini akan tidak ada apabila tidak di inisiasi dan diperjuangkan oleh Emil Salim berserta penggiat lingkungan hidup lainnya.

Menurut Marhani Abdul Kahar dkk, (1996, hlm. 44) dalam periode ini telah dilakukanpersiapanpenyusunanperangkat perundangan dan kelembagaan yang menangani pengelolaan lingkungan hidup. Penyusunan RUU Lingkungan Hidup telah dimulai pada tahun 1976 disertai persiapan pembentukan kelompok kerja hukum dan aparatur dalam pengelolaan sumberdaya alam dan lingkungan hidup. Pada periode ini beberapa peraturan perundangan yang terkait dengan lingkungan dihasilkan oleh berbagai instansi sektoral.

Lagi-lagi panitia kekayaan alam nyatanya juga tidak dapat bekerja 
dengan maksimal dikarenakan kurang memadainya prangkat yang kongsekuen dalam bidang inventarisasi dan evaluasi kekayaan alam. Dilain sisi, panitia ini kemudian menyadari betapa luas dan mendasarnya kajian maupun teknis dalam bidang kekayaan alam yang tentu menyangkut pula dengan lingkungan hidup serta sangat berintegrasi dengan beberapa sendi-sendi sosial dalam tatanan pemerintahan di negara yang dilintasi garis katulistiwa ini.

Diinisiasi oleh Emil Salim dan beberapa aktivis lingkungan yang bergerak diluar pemerintahan (Non Government Organitation) atau Ornop (Organisasi non Pemerintah) juga para cendekiawan lingkungan yang pada saat itu telah menyadari betapa pentingnya pengelolaan lingkungan untuk kepentingan Negara dan Masyarakat Indonesia, kemudian sepakatlah untuk membentuk suatu perangkat yang memiliki legitimasi kentara dan legalitas diatas hukum yang sungguh besar yang kemudian menjelma menjadi Kementerian pengawasan Pembangunan dan Lingkungan Hidup. Emil Salim mencoba untuk memulai pembicaraan yang bermuara untuk membentuk Kementerian Lingkungan Hidup kepada para pejabat negara yang bersangkutan diantaranya ialah dengan Menteri Sekretaris Negara dan Menteri Penertiban Aparatur Negara (SeknegRI, Keppres No. 28, 1978). Tidak ditemukannya secarik risalah yang menunjukan bahwa ada juga petemuan dengan aparatur terkait bagian kehutanan.

Untuk melaksanakan amanat GBHN 1978, maka berdasarkan Keppres No. 28 Tahun 1978 jo. Keppres No. 35 Tahun 1978, dalam Kabinet Pembangunan III diangkatlah Menteri Negara Pengawasan Pembangunan dan Lingkungan Hidup (Men-PPLH) dengan tugas pokok mengkoordinasikan pengelolaan lingkungan hidup di berbagai instansi pusat maupun daerah, khususnya untuk mengembangkan segi-segi lingkungan hidup pembangunan. Tugas pertama Menteri PPLH adalah mempersiapkan perumusan kebijaksanaan pemerintah mengenai pelaksanaan pembangunan dan pengelolaan serta pengembangan lingkungan hidup.

Jabatan Menteri ini diamanahkan kepada Emil Salim. Dalam upaya memantapkan koordinasi pengelolaan lingkungan di daerah, Menteri Dalam Negeri menindaklanjuti dengan menetapkan Keputusan Mendagri No. 240 Tahun 1980 tentang organisasi dan Tatakerja Sekretariat Wilayah/ Daerah Tingkat I dan Sekretariat DPRD Tingkat I yang didalamnya terdapat Biro Kependudukan dan Lingkungan Hidup (Azis dkk, 2010, hlm. 198).

Pencemaran, kata yang kemudian popular dengan "polusi”, di Dukuh Tapak merupakan kasus pertama yang ditangani Kementerian PPLH bersama kelompok 10 (terdiri dari beberapa LSM dan aktivis lingkungan) di tahun 1979. Kasus ini baru mulai mendapatkan perhatian ketika Emil Salim mencari dalang dari penebar polusi dan limbah di sungai-sungai Tapak Salatiga. Emil Salim akhirnya tergugah, karenaitu kasus pertamayang ditanganinya dan belum selesai dalam waktu lebih dari 10 tahun (Aditjondro, 2003a, hlm. 369). Dari pristiwa ini contohnya dan beberapa pristiwa yang "menggangu ketenangan" Kementerian PPLH kemudian merangsang Emil Salim untuk melahirkan suatu metode 
RANGGA DOLI P MANURUNG DAN AYI BUDI SANTOSA

AKAR YANG MENJALAR: PERAN EMIL SALIM DALAM KEMENTERIAN PENGAWASAN

PEMBANGUNAN DAN LINGKUNGAN HIDUP DI INDONESIA 1972-1983

penyelesaian kasus lingkungan yang kelak akan dilakukan oleh PPLH.

Seorang staf PPLH yang sudah pernah bekerja di lembaga pengendalian pencemaran di luar negeri (Australia) menyarankan agar PPLH segera melakukan usaha "potong kompas" dengan menyusun peringkat baku mutu dan tata kerja pentaatan, disusul kemudian dengan penegakan hukum. Saran ini dirasa pas porsinya ketika dihadapkan dengan fakta bahwa terlambatnya keberadaan atau pembentukan Kementerian PPLH dimana beberapa kerusakan pada lingkungan telah banyak terjadi. Kepada staf yang bersangkutan Emil Salim menjelaskan bahwa pendekatan seperti itu akan mempertajam konflik antar lembaga dan dampak jangka panjangnya akan merugikan upaya pelestarian lingkungan secara menyeluruh. Sebaliknya, yang dilakukan oleh Emil Salim cenderung "bermain cantik" namun tidak mengurangi indikator upaya pelestarian lingkungan dengan melaksanakan seperangkat strategi menurut Iwan J Azis dkk (2010, hlm. 216217) sebagai berikut:

1. Membangkitkan kesadaran lingkungan hidup secara luas, baik di pemerintahan maupun di masyarakat serta media. Yang termasuk dalam konteks ini antara lain adalah upaya mendukung dan mendorong berkembangnya lembaga swadaya masyarakat (LSM) di bidang pelestarian lingkungan hidup dan kemudian adalah program Piagam Kalpataru tahun 1981.

2. Meningkatkan kapasitas pengelolaan pelestarian lingkungan hidup di PPLH sendiri dan di lembaga pemerintahan lain disamping di kalangan aktivis lingkungan hidup. Upaya ini dilakukan antara lain dengan mengirim orangorang dari PPLH dan lembaga lain untuk belajar mengenai pelestarian lingkungan di luar negeri. Upaya lain dibidang itu adalah dibentuknya Pusat Studi lingkungan (PSL) tahun 1979 di berbagai perguruan tinggi.

3. Mengembangkan sarana bagi pengelolaan lingkungan seperti misalnya peraturan (Undang-Undang Lingkungan Hidup Nomor 4 Tahun 1982 dan Peraturan Pemerintah tentang Amdal 1986), baku mutu lingkungan, baku mutu limbah dan emisi dan sebagainya.

4. Dalam pengendalian dampak, khususnya pengendalian pencemaran, pelestarian media air menjadi prioritas karena pencemaran air sangat mempengaruhi kualitas hidup masyarakat berpendapatan rendah, selain itu intensitas serta sebarannya makin besar.

5. Dalam melakukan pentaatan, ditempuh pendekatan advokasi. Menghadapi kasus tertentu misalnya, Menteri PPLH mendatangi menteri sektoral yang bersangkutan dan para pemangku kepentingan lainnya untuk menjelaskan masalah. Dalam beberapa kasus, masalah berakhir ketika pemilik usaha mengatasi masalahnya atas perintah dari para menteri sektoral yang bersangkutan.

Poin-poin diatas yang lahir dari buah pemikiran Emil Salim atas beberapa pristiwa kerusakan lingkungan oleh perusahaan-perusahaan besar di Indonesia kemudian diaplikasikan oleh Emil Salim sebagai dasar pokok tujuan dari beberapa kebijakan dan program-programnya kelak. Sebagai sebuah instansi yang baru berdiri, 
tidak melulu mengupayakan "penertiban" bagi para pemain-pemain nakal atas lingkungan, namun ada pentingnnya untuk membangun dan membius massa agar terciptanya kesadaran atas pentingnnya lingkungan hidup.

Menurut peneliti, hal ini seperti pisau bermata dua, adabenarnya ketika pimpinan dari suatu instansi atau organisasi yang baru berdiri lebih mengupayakan jalan damai dengan pendekatan-pendekatan yang sejuk ketimbang melakukan hal sebaliknya. Namun, disisi lain seolah-olah terlihat lari dari tanggung jawab atas tugas pokok fungsi dan tatakerja yang telah di amanahkan negara.

\section{Kebijakan Emil Salim dalam Kementerian Pengawasan Pembangunan dan Lingkungan Hidup 1978-1983}

\section{Pusat Studi Lingkungan (PSL) Tahun 1979}

Dirasa kurangnya wawasan mengenai lingkungan hidup dan perlunya suatu lembaga yang berfokus mengenai kajiankajian lingkungan hidup, Emil Salim kemudian membentuk Pusat Studi Lingkungan pada tahun 1979. Lembaga ini dinaungi oleh perguruan tinggi negeri maupun swasta yang bertanggung jawab langsung kepada Kementerian Pengawasan Pembangunan dan Lingkungan Hidup. Tujuan dibentuknya PSL ini antara lain adalah melakukan analisis mengenai lingkungan dengan penelitian-penelitian yang berkaitan pula dengan lingkungan.

Selain itu, menurut Wisaksono Noeradi (2000, hlm. 25) karena yakin juga bahwa Kantor Menteri Negara PPLH yang kecil itu tidak akan mampu memahami segala aspek masalah lingkungan hidup, kami mengembangkan Pusat Studi Lingkungan (PSL) di semua universitas atau institut. ini merupakan hal yang bijak yang dilakukan oleh Emil Salim, selain tidak mengurangi ruang kantor Menteri PPLH, PSL yang ada dibeberapa daerah di Indonesia juga meneliti dan mengkaji lingkungan di wilayah PSL dan Universitas itu berada. Dengan kata lain PSL ini juga memberikan laporan-laporan kepada PPLH terkait masalah lingkungan didaerah PSL itu berada yang kemudian mempermudah PPLH untuk mengkaji dan menangani permasalahan lingkungan di daerahdaerah dimana PSL itu bernaung.

Selain memperluas cakupan kerja PPLH,keberadaanPSLinijugamemberikan wawasan dan pengetahuan mengenai lingkungan kepada mahasiswa dan kalangan cendekiawan. Artinya semakin banyak juga kalangan cendekiawan yang dibuat sadar mengenai wawasan lingkungan. Dengan begitu PSL ini juga menjadi suatu metode "reklame" yang efisien serta mempermudah PPLH untuk membangkitkan kesadaran lingkungan hidup secara luas. Disamping itu PSL juga aktif dalam memberikan masukanmasukan mengenai penangannan kerusakan lingkungan tentu dengan kajian-kajian teoritis dan analisis yang telah diperkirakan matang-matang oleh kalangan yang ahli dalam bidangnya.

Beberapa pencapaian yang berhasil dibuat oleh Pusat Studi Lingkungan salah satunya ialah pelaksanaan kajian mengenai Analisis Dampak Lingkungan atau AMDAL yang turut menjadi barometer dan pertimbangan untuk pembangunan pada saat itu. Amdal ini menjadi cikal bakal persyaratan dimana pembangunan suatu gedung 
RANGGA DOLI P MANURUNG DAN AYI BUDI SANTOSA

AKAR YANG MENJALAR: PERAN EMIL SALIM DALAM KEMENTERIAN PENGAWASAN

PEMBANGUNAN DAN LINGKUNGAN HIDUP DI INDONESIA 1972-1983

di suatu wilayah perlu memperhatikan dampak dari pembangunan tersebut, imbas bagi lingkungan sekitar, dan efek pembangunan tersebut untuk ekosistem lingkungan jangka panjang. Hal ini cukup memberikan sumbangsih yang besar dimana pembangunan kemudian tidak lagi dilakukan tanpa perhitungan atau analisis lingkungan.

\section{Piagam Kalpataru Tahun 1982}

Strategi Emil Salim untuk membangkitkan kesadaran lingkungan hidup secara luas, baik di pemerintahan maupun di masyarakat serta media selanjutnya yang aplikasikan dalam bentuk progam kerja ialah Piagam Kalpataru yang mulai diperkenalkan pada tahun 1981. Penghargaan dengan labang "Pohon Kehidupan" ini diberikan kepada masyarakat yang memelihara lingkungan hidup dengan kesadaran sendiri tanpa mengharapkan imbalan dan prestasinya dinilai luar biasa. Pemberian penghagaan Kalpataru biasanya dilakukan pada saat puncak peringatan Hari Lingkungan Hidup, tanggal 5 Juni setiap tahunnya, mengikuti ketentuan dari United Nation Environment Programme (UNEP) (Azis dkk, 2010, hlm. 200).

Penghargaan untuk para pahlawan lingkungan hidup telah dimulai pada tahun 1980 berupa sebuah plaket. Di atas permukaan plaket tertera tulisan "Hadiah Lingkungan" dengan tambahan "Tahun 1980". Pada saat itu pemerintah memberikan penghargaan kepada delapan organisasi dan kelompok masyarakat atas jasa-jasanya pada usaha pelestarian lingkungan. Penghargaan yang diberikan hanya berupa plakat yang di tengahnya tertera tulisan "Hadiah Lingkungan" dan “Tahun 1980".
Penerima penghargaan "Hadiah Lingkungan Tahun 1980" ini adalah LP3ES (Lembaga Penelitian, Pendidikan dan Penerangan Ekonomi dan Sosial), Jakarta; Pondok Pesantren Cipasung, Tasikmalaya (Jawa Barat); Pondok Pesantren Suralaya, Tasikmalaya (Jawa Barat); Badan Sosial Maumere, Flores (NTT); Masyarakat Kabupaten Sikka, Sikka (NTT); Dian Desa, Sleman (Yogyakarta); Masyarakat Kepuharjo, Kecamatan Cangkringan, Kabupaten Sleman (Yogyakarta) serta Masyarakat Desa Wonolelo, Kecamatan Sawangan, Kabupaten Magelang (Jawa Barat). Tahun-tahun selanjutnya atau sejak tahun 1981 "Hadiah Lingkungan" ini memiliki nama baru yaitu Penghargaan Piagam Kalpataru ketika ditemukannya suatu relief yang menggambarkan pohon kehidupan.

\section{Undang-undang Nomor 4 Tahun 1982}

Selanjutnya Emil Salim memberlakukan Hukum Undang-Undang Nomor 4 Tahun 1982 sebagai kebijakan hukumnya atas pengembangan sarana bagi pengelolaan lingkungan di bidang peraturan. Sejak era 1980an, berkembang tuntutan yang meluas agar kebijakankebijakan resmi negara yang mendukung lingkungan dapat tercermin dalam bentuk perundang-undangan yang mengingat untuk ditaati oleh semua pemangku kepentingan (stakeholder). Tak terkecuali Indonesia yang juga menghadapi tuntutan yang sama, yaitu perlu disusunnya suatu kebijakan yang dapat dipaksakan berlakunya dalam bentuk undang-undang tersendiri yang mengatur mengenai lingkungan hidup.

Itu juga sebabnya, Indonesia menyusun Undang-undang Lingkungan Hidup dan 
pada tanggal 11 Maret 1982 Indonesia akhirnya menetapkan berlakunya Undangundang Nomor 4 Tahun 1982 tentang Ketentuan-Ketentuan Pokok Pengelolaan Lingkungan Hidup (Undang-Undang Lingkungan Hidup 1982). Inilah produk hukum pertama yang dibuat di Indonesia sekaligus produk hukum pertama yang dibuat oleh Kementerian Pengawasan Pembangunan dan Lingkungan Hidup dibawah pengawasan Emil Salim. Menurut Jimly Asshiddiqie (2010, hlm. 31), sebagai menteri pertama di Kementerian ini, Emil Salim berhasil meletakkan dasar-dasar kebijakan mengenai lingkungan hidup dan akhirnya dituangkan dalam bentuk undang-undang pada tahun 1982.

Lahirnya Undang-Undang Lingkungan Hidup 1982 dipandang sebagai pangkal tolak atau awal dari lahir dan pertumbuhan hukum lingkungan nasional. Sebelum lahirnya Undang-Undang Lingkungan Hidup 1982 sesungguhnya telah berlaku berbagai bentuk peraturan perundangundangan tentang atau yang berhubungan dengan lingkungan hidup atau sumber daya alam dan sumber daya buatan, yang dipandang sebagai rezim hukum nasional klasik. Rezim hukum lingkungan klasik berisikan ketentuan-ketentuan yang melindungi kepentingan sektoral, sementara masalah-masalah lingkungan yang timbul semakin kompleks sehingga peraturan perundang-undangan klasik tidak mampu mengantisipasi dan menyelesaikan masalah-masalah lingkungan secara efektif, sedangkan rezim hukum lingkungan modern dimulai ketika lahirnya Undang-Undang Lingkungan Hidup 1982 berdasarkan pendekatan lintas sektoral atau komprehensif integral (Rahmadi, 2011, hlm. 77).
Undang-Undang Lingkungan Hidup 1982 merupakan sumber hukum formal tingkat undang-undang yang pertama dalam konteks hukum lingkungan modern di Indonesia. Undang-Undang Lingkungan Hidup 1982 memuat ketentuan-ketentuan hukum yang menandai lahirnya suatu bidang hukum baru, yakni hukum lingkungan karena ketentuan-ketentuan itu mengandung konsep-konsep yang sebelumnya tidak dikenal dalam bidang hukum.

Konsekuensi politik dari dilibatkannya isu permasalahan pembangunan lingkungan hidup sebagai salah satu agenda kebijakan dan program pembangunan nasional dalam GBHN Tahun 1978, adalah diharuskannya pemerintah untuk membentuk institusi khusus yang menangani pengelolaan lingkungan hidup. Oleh karena itu, pada Repelita III Presiden Soeharto mengangkat seorang Menteri Negara dalam Kabinet Pembangunan III yang menangani permasalahan pembangunan lingkungan hidup, yaitu Menteri Negara Pengawsan Pembangunan dan Lingkungan Hidup.

Sebelum penulis paparkan dampak dari kebijakan Emil Salim sebagai Menteri Negara Pengawasan Pembangunan dan Lingkungan Hidup secara mendetail, ada dampak dari seluruh kebijakan serta progam-program yang terwakilkan oleh Pusat Studi Lingkungan (PSL) tahun 1979, Produk Hukum Undang-Undang No. 4 Tahun 1982 dan Piagam Penghargaan Kalpataru tahun 1981 yang Emil Salim berserta Men-PPLH telah laksanakan dengan Tabel 5.1 berdasarkan laporan Departemen Kehutanan dari Rakornas I Pengelolaan Lingkungan Hidup dan Pembangunan Berkelanjutan tahun 1994 sebagai berikut: 
RANGGA DOLI P MANURUNG DAN AYI BUDI SANTOSA

AKAR YANG MENJALAR: PERAN EMIL SALIM DALAM KEMENTERIAN PENGAWASAN

PEMBANGUNAN DAN LINGKUNGAN HIDUP DI INDONESIA 1972-1983

Tabel 5.1 Kondisi Lahan Kritis pada 39 SWP DAS

\begin{tabular}{|l|l|}
\hline Periode & $\begin{array}{l}\text { Luas Besaran } \\
\text { (ha) }\end{array}$ \\
\hline Awal Pelita III & 11.073 .300 ha \\
\hline Awal Pelita IV & 10.415 .000 ha \\
\hline Awal Pelita V & 13.188 .200 ha \\
\hline Awal Pelita VI & 11.003 .317 ha \\
\hline
\end{tabular}

(Sumber Tabel: Almanak Lingkungan Hidup Indonesia 1995/1996 karya Marhani Abdul Kahar dkk, 1996, hlm. 10)

Dari tabel 5.1 dapat dinilai terjadinya penurunan pada awal Pelita IV atau selisih kurang lebih satu tahun dari selesainya masa tugas Kementerian PPLH ini. Adanya penurunan lahan kritis yang cukup besar mengindikasikan bahwa programprogram serta kebijakan yang telah Emil Salim dan Kementerian PPLH ini lakukan cukup sukses walaupun dapat dikatakan jauh dari kata berhasil. Berbeda setelahnya selesainya Pelita IV dan memasuki Pelita $\mathrm{V}$ ada kenaikan ikan jumah luas kondisi lahan kritis.

\section{Ruang Lingkup Pusat Studi Lingkungan Tahun 1979}

Keberadaan Pusat Studi Lingkungan pada tahun-tahun pertama keberadaan Kementerian PPLH ini dinilai cukup membantu beberapa tugas besar PPLH sesuai dengan tugas pokok dan fungsi dari kementerian ini. Sebagai "laboratorium", PSL juga memberikan kontribusi aktif baik dari sisi pengkajian, pengembangan ilmu pengetahuan dan analisis dampak lingkungan yang ada diwilayah perguruan tinggi tersebut juga memberikan saran penanganan dampak lingkungan yang dianggap dapat menyelesaikan permasalahan lingkungan yang ada. PSL juga aktif memberikan kritik kepada PPLH ataupun kepada Biro Kependudukan dan Lingkungan Hidup dalam Sekretariat DPDR Tingkat I apabila proses penanggulangan ekosistem yang dilakukan instansi dianggap bukan metode yang sesuai atau yang terbaik (Suparmoko, 1997, hlm. 39). Sebagai suatu badan yang berada dibawah perguruan tinggi, tentu hal ini ditindak lanjuti sesuai dengan garis struktural yang pada akhirnya sampai ke Kementerian PPLH.

Hal tersebut tentu memiliki kekurangan, garis struktural yang ada menyebabkan terjadinya proses yang panjang tersampaikannya suatu laporan dari PSL kepada PPLH. Akan memakan waktu yang cukup lama apabila suatu kerusakan lingkungan yang parah terjadi dan perlu penanggulangan sesegera mungkin, namun informasi yang diberikan oleh PSL melewati cukup banyak "pintu" agar sampai ke Kementerian PPLH di Jakarta.

Tugas PSL adalah tidak saja bertindak sebagai lembaga pembantu Pemerintah Daerah khususnya Biro Kependudukan dan Lingkungan Hidup dalam rangka memecahkanmasalah-masalahlingkungan hidup di wilayah administratifnya, akan tetapi mendapat pula tugas dari MenPPLH untuk ikut memberikan kontribusi mengenai suatu aspek tertentu di bidang lingkungan hidup yang sejauh mungkin dikaitkan dengan Pola Ilmiah Pokok (PIP) universitas/institut yang bersangkutan. di Indonesia perkembangan penyelenggaraan pendidikan lingkungan dimulai pada tahun 1975 dimana IKIP Jakarta untuk pertama kalinya merintis pengembangan pendidikan lingkungan dengan menyusun Garis-garis Besar Program Pengajaran Pendidikan Lingkungan Hidup yang diujicobakan di 15 Sekolah Dasar Jakarta pada periode tahun 1977-1978 (Sudjoko, t.th, hlm. 1.5-1.8). 
Dapat dikatakan, PPLH memiliki relawan-relawan lingkungan yang akan siap membantu PPLH untuk menyadarkan masyarakat luas mengenai pentingnya lingkungan, untuk menyampaikan aspirasi masyarakat mengenai kegiatan perusahaan-perusahaan raksasa yang dianggap merusak atau mencemari lingkungan sehingga hal demikian menjadikan masyarakat kesulitan baik secara ekonomi, maupun kesehatan seperti yang terjadi di Kalimantan ketika ada peambangan kayu yang menjadikan daerah sekitar kemudian terendam banjir akibat gundulnya beberapa lokasi serapan air. Beberapa program dari kementerian PPLH dirasa tidak akan berjalan dengan signifikan apabila tidak ada campur tangan dari PSL

\section{Pelaksanaan Piagam Kalpataru Tahun 1982}

Kalpataru adalah penghargaan tertingi berskala Nasional di bidang lingkungan hidup yang diberikan oleh Pemerintah Indonesia. Penghargaan Kalpataru ini berangkat dari konsep Emil Salim yang bertujuan untuk meningkatkan kesadaran lingkungan hidup secara luas baik di pemerintahan maupun di masyarakat serta media. Dari konsep tersebutlah lahir program kerja Piagam Kalpataru sebagai kebijakan Menteri Emil Salim di Kementerian PPLH.

Piagam Kalpataru diberikan kepada perorangan atau kelompok masyarakat yang telah menunjukkan kepeloporannya dalam melestarikan fungsi lingkungan dan memberikan sumbangsih bagi upayaupaya pemeliharaan fungsi ekosistem. Penghargaan diberikan setiap tahun bertepatan pada Hari Lingkungan Hidup Sedunia setiap tanggal 5 Juni oleh
Presiden. Penghargaan ini bertujuan untuk merangsang dan memotivasi peran aktif masyarakat dalam melestarikan fungsi lingkungan dalam bentuk pengabdiannya masing-masing. Melalui pemberian penghargaan ini diharapkan bisa mengangkat kepeloporan dan keteladanan serta mensosialisasikannya kepada masyarakat luas. Penghargaan ini sudah dimulai sejak tahun 1981 dengan empat kategori penghargaan, yaitu Perintis Lingkungan, Pengabdi Lingkungan, Penyelamat Lingkungan dan Pembina Lingkungan.

\section{Penerapan Hukum Undang- Undang Nomor 4 Tahun 1982}

Penyusunan Rancangan UndangUndang (RUU) Lingkungan Hidup berangkat dari konsep pembangunan berkelanjutan hasil dari konferensi Stockholm tahun 1972 yang kemudian di modifikasi oleh Emil Salim agar sesuai dengan keadaan di Indonesia. Selanjutnya penyusunan RUU ini dimulai pada tahun 1976 disertai persiapan pembentukan kelompok kerja hukum dan aparatur dalam pengelolaan sumberdaya alam dan lingkungan hidup yang pengerjaannya dikawal oleh juga Emil Salim (Emil Salim, 1979, hlm. 68). Kemudian RUU ini menjadi Undang-Undang Nomor 4 Tahun 1982 tentang Ketentuan-Ketentuan Pokok Pengelolaan Lingkungan Hidup sebagai sebuah produk hukum dan kebijakan Emil Salim.

Dengan adanya undang-undang ini kesadaran masyarakat Indonesia akan arti penting untuk memelihara lingkungan hidup mulai tumbuh. Untuk menindaklanjuti undang-undang tersebut kemudian ditetapkan Peraturan Pemerintah (PP) No. 29 Tahun 1986 
RANGGA DOLI P MANURUNG DAN AYI BUDI SANTOSA

AKAR YANG MENJALAR: PERAN EMIL SALIM DALAM KEMENTERIAN PENGAWASAN PEMBANGUNAN DAN LINGKUNGAN HIDUP DI INDONESIA 1972-1983

tentang Analisis Mengenai Dampak Lingkungan (AMDAL) yang merupakan pedoman pelaksanaan suatu proyek pembangunan. Setiap proyek yang diperkirakan memiliki dampak penting diharuskan melakukan studi AMDAL. Pada tahun 1997 Pemerintah Indonesia telah memperbarui Undang-Undang No. 4 Tahun 1982 dengan Undang-Undang No. 23 Tahun 1997 tentang Pengelolaan Lingkungan Hidup.

Selanjutnya berdasarkan UndangUndang No. 23 Tahun 1997 jo UndangUndang No. 4 Tahun 1982, kelembagaan pelaksana atau penyelenggara kebijakan nasional di bidang lingkungan hidup bukan hanya Kementerian Lingkungan Hidup saja, melainkan semua Departemen atau LPND, pemerintah daerah, sektor swasta dan organisasi masyarakat juga ikut bertanggung jawab. Selain itu untuk mengurangi dampak lingkungan akibat kegiatan pembangunan yang semakin pesat maka dibentuklah sebuah badan yang lebih bersifat oprasional yakni Badan Pengendalian Dampak Lingkungan (Bapedal) yang dibentuk berdasarkan Keputusan Presiden (Keppres) No. 23 Tahun 1990. Tugas Bapedal ini adalah melaksanakan pemantauan dan pengendalian kegiatan-kegiatan pembangunan yang berdampak penting terhadap lingkungan hidup (Rispa dan Chazienul, 2017, hlm. 31-32).

\section{SIMPULAN}

Sebelum Emil Salim menjadi menteri Pengawasan Pembangunan dan Lingkungan Hidup, Emil Salim juga berperan aktif dalam mengawali proses pembentukan kementerian ini. Kebijakankebijakan yang dibuat Emil Salim saat menjabat sebagai Menteri Pengawasan Pembangunan dan Lingkungan Hidup pada periode 1978- 1983 memberikan dampakpenting terhadapkeberlangsungan lingkungan hidup di Indonesia. Emil Salim berperan aktif memberikan kesadaran kepada masyarakat dari berbagai golongan di Indonesia untuk menjaga serta mengawasi pembangunan dan lingkungan hidup.

Sebagai seorang menteri pertama dalam kementerian yang baru terbentuk, kebijakan Emil Salim dinilai tepat karena dari analisis penulis kebijakankebijakannya adalah upaya untuk mendulang pemahaman serta kesadaran mengenai pentingnya lingkungan hidup lewat kebijakan Program Studi Lingkungan (PSL) dan Program Kalpataru dan selanjutnya mematenkan suatu produk hukum Undang-Undang No.4 Tahun 1982 yang dalam undang-undang ini juga menggantikan nama Organisasi Non Pemerintah (Ornop) menjadi Lembaga Swadaya Masyarakat (LSM). Dengan analisis demikian, inilah yang penulis artikan sebagai “Akar Yang Menjalar”.

\section{DAFTAR PUSTAKA}

Abdurahman, D. (2007). Metodologi Penelitian Sejarah. Yogyakarta: ArRuz Media.

Aditjondro, G.J. (2003a). KebohonganKebohongan Negara: Perihal Kondisi Obyektif Lingkungan Hidup di Nusantara. Yogyakarta: Pustaka Pelajar.

Asshiddiqie, J. (2010). Green Constitution. Jakarta: Rajawali Pers.

Aziz, I.J dkk. (Ed). (2010). Pembangunan Berkelanjutan Peran dan Kontribusi Emil Salim. Jakarta: KPG. 
Chazienul U.M \& Rispa N. (2017). Suparmoko, M. (1997). Ekonomi Environmental Governance: Sumberdaya Alam dan Lingkungan: Isu, Kebijakan dan Tata kelola Suatu Pendekatan Teoritis. Lingkungan. Malang: UB Press.

Yogyakarta: BPFE.

Gottschalk, L. (2008). Mengerti Sejarah. Wiryono. (2013). "Prakarta" dalam Jakarta: UI Press.

Ismaun. (2005). Pengantar Belajar Sejarah sebagai Ilmu dan Wahana Pendidikan. Bandung: Historia Utama Press.

Kahar, M.A dkk. (1996). Almanak Lingkungan Hidup Indonesia 1995/1996. Jakarta: Kantor Menteri Negara Lingkungan Hidup.

Noeradi, W. (Ed). (2000). 70 Tahun Emil Salim: Revolusi Berhenti di Hari Minggu. Jakarta: Kompas.

Rahmadi, T. (2011). Hukum Lingkungan di Indonesia. Jakarta: Rajawali Pers.

Salim, E. (1979). Lingkungan Hidup dan Pembangunan. Jakarta: Mutiara.

Salim, E. (2000). Kembali ke Jalan Lurus: Esai-Esai 1966-99. Jakarta: AlvaBet. Sjamsuddin, H. (2012). Metodologi Sejarah. Yogyakarta: Ombak.

Sudjoko, M.S. (t.th). Perkembangan dan Konsep Dasar Pendidikan Lingkungan Hidup. PEBI 4223/Modul 1 buku Pengantar ilmu Lingkungan. Bengkulu: Pertelon Media.

Sekneg RI [Sekretaris Negara Republik Indonesia]. (1975). "Keputusan Presiden Nomor 27 Tahun 1975. Tentang Pembentukan Panitia Inventarisasi dan Evaluasi Kekayaan Alam”. Naskah Tidak Diterbitkan. Jakarta: Sekretaris Negara RI.

Sekneg RI [Sekretaris Negara Republik Indonesia]. (1978). "Keputusan Presiden Nomor 28 Tahun 1978 jo dan Keputusan Presiden Nomor 35 Tahun 1978. Tentang (Kabinet Pembangunan III) pembentukan Kementerian Pengawasan Pembangunan dan Lingkungan Hidup (Men-PPLH)”. Naskah Tidak Diterbitkan. Jakarta: Sekretaris Negara RI. 